\title{
PERBANDINGAN KARAKTER PESERTA DIDIK TOYOTA TECHNICAL EDUCATION PROGRAM DENGAN PROGRAM REGULER
}

\author{
Muhammad W. Hambali' ${ }^{1}$, Tatang Permana ${ }^{2}$, Mumu Komaro ${ }^{3}$ \\ Universitas Pendidikan Indonesia \\ Jl. Dr. Setiabudhi No. 207 Bandung 40154 \\ wahidhambali16@gmail.com
}

\begin{abstract}
ABSTRAK
Tujuan penelitian ini untuk mengetahui profil dari karakter peserta didik kelas Toyota Technical Education Program (TTEP) dengan kelas reguler Teknik Kendaraan Ringan SMKN 6 Bandung. Metode penelitian ini adalah penelitian deskriftif dengan pendekatan kuantitatif. Populasi dalam penelitian ini adalah peserta didik SMK Negeri 6 Bandung kelas XI, keahlian Teknik Otomotif, paket keahlian Teknik Kendaraan Ringan yang berjumlah 209 siswa. Sampel penelitian menggunakan nonprobability sampling dengan jumlah 67 orang. Kelas TTEP berjumlah 30 orang dan kelas regular yang berjumlah 37 orang. Instrumen penelitian menggunakan angket. Hasil penelitian menunjukan bahwa karakter peserta didik pada kelas TTEP secara umum masuk dalam kategori sangat baik dengan persentase keseluruhan yaitu sebesar $83 \%$. Karakter peserta didik pada kelas regular didapatkan skor persentase keseluruhan yaitu 62\% masuk dalam kategori baik. Kesimpulan penelitian ini yaitu bahwa ada perbedaan karakter peserta didik antara kelas TTEP dan kelas reguler.
\end{abstract}

Kata kunci: toyota technical education program, teknik kendaraan ringan, teknik otomotif

\section{PENDAHULUAN}

Perkembangan zaman dan kemajuan teknologi saat ini sangatlah cepat, begitupun juga dengan kemajuan dalam dunia pendidikan. Pendidikan adalah suatu kegiatan menyangkut interaksi kejiwaan antara pendidik dan peserta didik dalam suasana nilai-nilai budaya suatu masyarakat (sebagai lingkungan pendidikan) yang didasarkan pada nilai-nilai kemanusiaan (Slamet, 2011). Pendidikan selalu melibatkan aspek-aspek tertentu: kejiwaan, kebudayaan, kemasyarakatan, norma-norma, dan kemanusiaan.

Proses pendidikan di dalamnya terdapat guru sebagai peran penting tenaga kependidikan yang dapat melayani perbedaan dari masing-masing peserta didiknya hingga terjadinya suatu proses interaksi, proses tersebut yang dinamakan proses belajar mengajar. Belajar merupakan suatu proses yang tak terpisahkan dengan perkembangan individu dan juga sudah menjadi bagian hidup dari individu itu sendiri (Darmadi, 2017). Belajar adalah serangkaian kegiatan jiwa raga untuk memperoleh suatu perubahan tingkah laku sebagai hasil dari pengalaman individu

\footnotetext{
${ }^{1}$ Mahasiswa Departemen Pendidikan Teknik Mesin FPTK UPI

2 Dosen Departemen Pendidikan Teknik Mesin FPTK UPI

${ }^{3}$ Dosen Departemen Pendidikan Teknik Mesin FPTK UPI
} 
dalm interaksi dengan lingkungan yang menyangkut kognitif, afektif dan psikomotorik (Djamarah, 2008). Beriringan dengan pertumbuhan dan perkembangan suatu individu maka proses belajar pun juga akan semakin berkembang. Jika terdapat suatu proses, maka akan ternilai dengan hasil ahir. Hasil belajarpun tak selamanya bernilai baik ataupun positif, namun juga masih banyak saat ini tecatat hasil belajar yang kurang baik. Baik buruknya suatu hasil belajar juga akan menentukan kualitas dari pendidikan itu sendiri.

Pendidikan tidak hanya membentuk insan Indonesia yang cerdas, namun juga berkepribadian atau berkarakter (Asmani, 2012). Sehingga dengan amanah tersebut diharapkan lahir generasi bangsa yang berprestasi danjuga berkarakter baik. Pendidikan tidak hanya bertujuan menghasilkan prestrasi akademik saja. Namun, ada hal perkembangan psikologi ataupun karakter yang baik pada individu ataupun peserta didik (Sitanggang dan Saragih, 2013). Kondisi saat ini masih berbalik dengan apa yang menjadi harapan. Masih banyak kita mendengar terjadi peristiwa yang dilakukan peserta didik. Peserta didik, khususnya Sekolah Menengah Kejuruan masih ada hal yang tidak diharapkan oleh masyarakat dan pemerintah seperti perkelahian diantara kalangan remaja, pencurian, pelanggaran lalu lintas, penyimpangan norma-norma dalam hal pergaulan dan sebagainya. Karakter pelajar sudah mulai lemah terlihat dari banyak kasus yang dilakukan oleh peserta didik. Tawuran pelajar, pornografi, menyontek, penyalahgunaan narkoba dan kekerasan peserta didik adalah hal hal yang kerap terjadi.

Praktik pendidikan di Indonesia cenderung berorientasi pada pendidikan berbasis hard skill (keterampilan teknis), yang lebih bersifat intelligence quotient (IQ) sedangkan kemampuan soft skill yang tertuang dalam emotional intelligence (EQ) dan spiritual intelligence (SQ) sangat kurang (Asmani, 2012). Sedangkan pada kondisi idealnya adalah dimana karakter yang kuat dan prestasi yang tinggi merupakan cerminan manusia berkualitas. Bahwa $80 \%$ keberhasilan seseorang dalam masyarakat di pengaruhi oleh kecerdasan emosi, dan hanya $20 \%$ ditentukan oleh kecerdasan otak (IQ). Salah satu kecerdasan emosi yang dimaksud dalam hal ini adalah karakter diri (Sunarto, et. al., 2008).

Masih ditemukan perbedaan yang sangat identik antara peserta didik kelas TTEP dengan kelas regular yang lain. Beberapa perbedaaan yang terjadi itu diantaranya dari hasil belajar. Dimana dalam ujian tengah semester ataupun kenaikan di kelas TTEP tidak ada yang mengikuti remedial atau semua lulus diatas nilai KKM. Sedangkan di kelas regular yaitu XI TKR 4 masih ada siswa yang mengikuti remedial pada Ujian Tengah Semeser. Sebanyak 17 siswa dari 32 
mendapat nilai di bawah standar dan mengikui ujian remedial. Selain itu, pada kelas reguler masih banyak tercatat siswa yang tidak hadir tanpa keterangan. Dalam satu semester tercatat 10 siswa pernah tidak hadir tanpa keterangan. Hasil pengamatan bahwa rasa tanggung jawab dan kejujuran peserta didik juga rendah dalam mengumpulkan tugas. Kondisi dan hasil tersebut masih tidak jauh berbeda dengan tes ulangan harian pada ajaran baru saat ini. Pendidikan berfungsi mengembangkan kemampuan dan membentuk karakter serta peradaban yang bermartabat dalam rangka mencerdaskan kehidupan bangsa (Lestari dan Sukanti, 2016). Untuk itu perlu diketahuinya bagaimana karakter peserta didik TTEP ataupun reguler. Terutama dalam kelas TTEP yang tercatat memiliki prestasi belajar lebih baik dengan kelas yang lain.

\section{METODE PENELITIAN}

Penelitian ini menggunakan metode deskriptif dengan pendekatan kuantitaif. Penelitian deskriptif digunakan untuk menganalisa data yang telah terkumpul dengan cara mendeskripsikan atau menggambarkan objek yang telah diteliti melalui sampel atau populasi sebagaimana adanya tanpa melakukan analisa dan membuat kesimpulan yang berlaku umum. Metode deskriptif dalam penelitian ini, dimaksudkan untuk mengetahui karakter peserta didik program TTEP dengan program regular kelas XI SMK Negeri 6 Bandung. Populasi penelitian pada penelitian ini adalah peserta didik SMK Negeri 6 Bandung keahlian Teknik Otomotif, paket keahlian Teknik Kendaraan Ringan. Metode pengambilan sampel menggunakan nonprobability sampling dengan cara sampling purpose sebanyak 67 orang.

Instrumen yang digunakan yaitu angket atau kuesioner yang kemudian diberikan kepada sampel terpilih. Uji validitas instrumen yang digunakan validitas konstruk. Validitas konstruk diperoleh dengan cara uji validitas atau meminta pertimbangan kepada para ahli (expert judgement). Data yang telah diperoleh tersebut diolah dengan menggunakan rumus perhitungan rata-rata persentase.

\section{HASIL PENELITIAN}

Hasil penelitian terkait dengan karakter peserta didik kelas TTEP ditunjukkan pada Gambar 1. Sifat dari peserta didik pada kelas TTEP rata-rata 83\%. Artinya peserta didik untuk kelas TTEP memiliki sifat atau karakter berkategori sangat baik. 


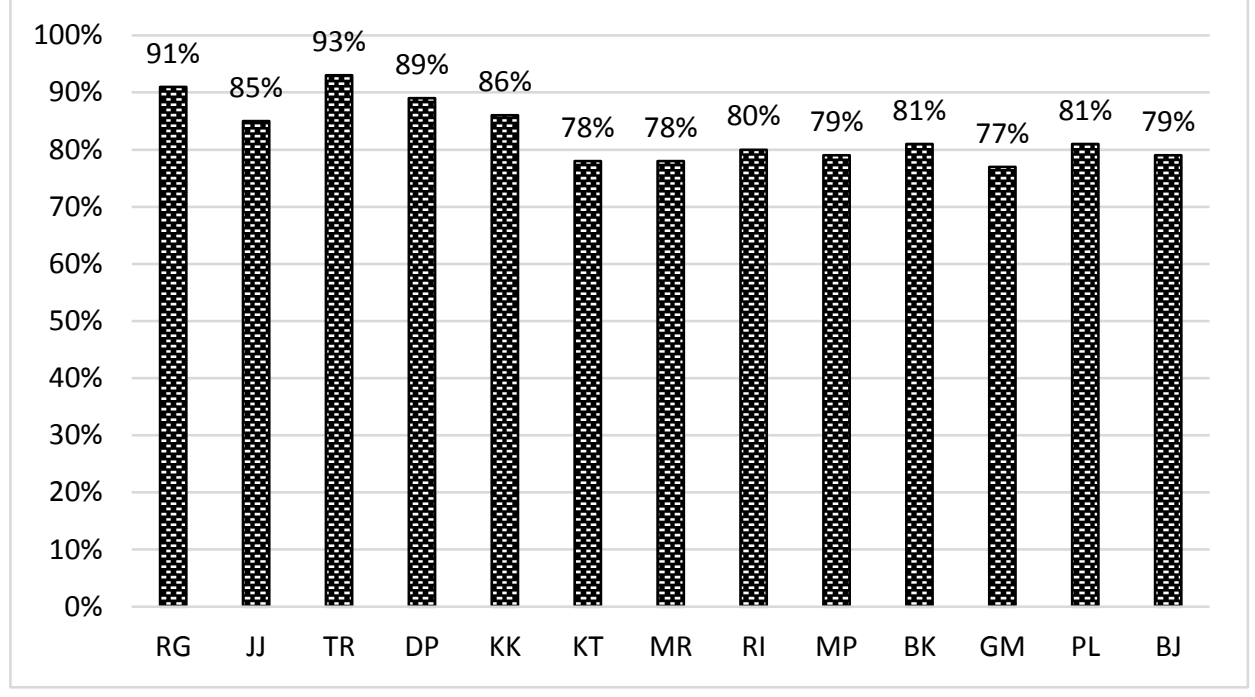

Gambar 1. Profil karakter peserta didik kelas TTEP

Keterangan: $\mathrm{RG}=$ religius, $\mathrm{JJ}=$ jujur, $\mathrm{TR}=$ toleran, $\mathrm{DP}=$ disiplin, $\mathrm{KK}=$ kerja keras, $\mathrm{KT}=$ kreatif, $\mathrm{MR}=$ mandiri, $\mathrm{RI}=$ rasa ingin tahu, $\mathrm{MP}=$ menghargai prestasi, $\mathrm{BK}=$ bersahabat, $\mathrm{GM}=$ gemar membaca, $\mathrm{PL}=$ peduli dan $\mathrm{BJ}=$ bertanggung jawab.

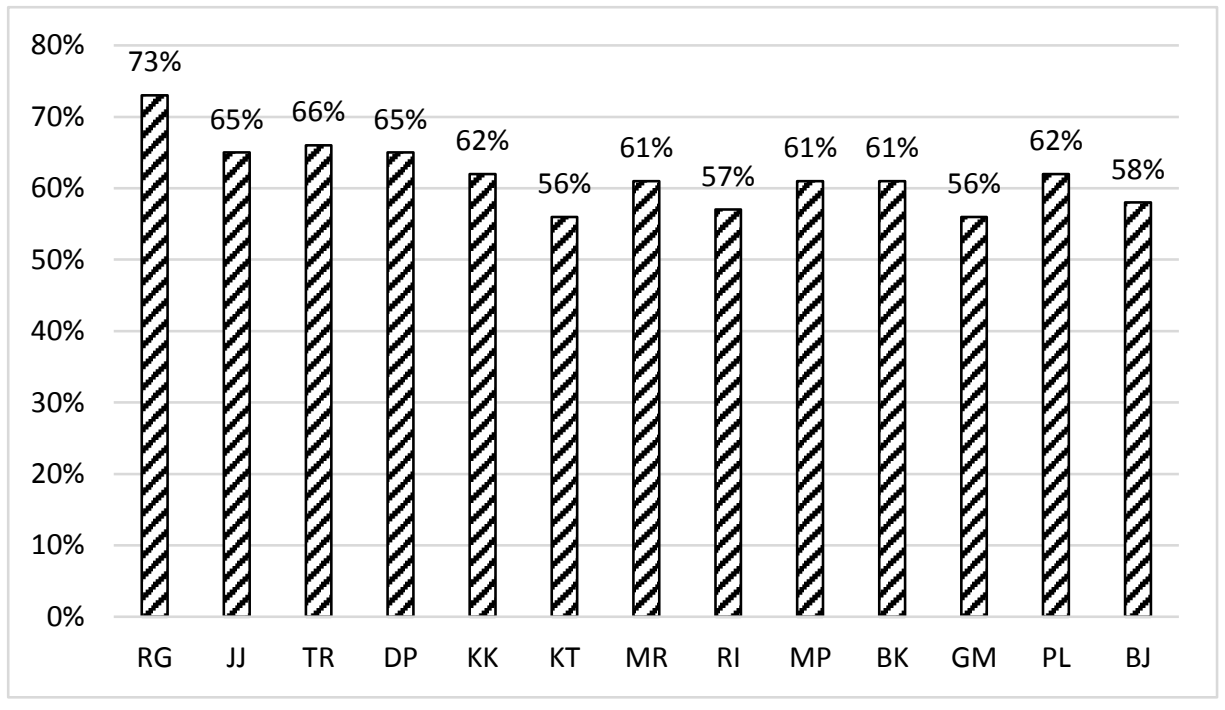

Gambar 2. Profil karakter peserta didik kelas reguler

Hasil penelitian karakter peserta didik kelas reguler ditunjukkan pada Gambar 2. Karakter dari peserta didik pada kelas reguler rata-rata 62\%. Artinya peserta didik untuk kelas reguler memiliki sifat atau karakter berkategori baik. 


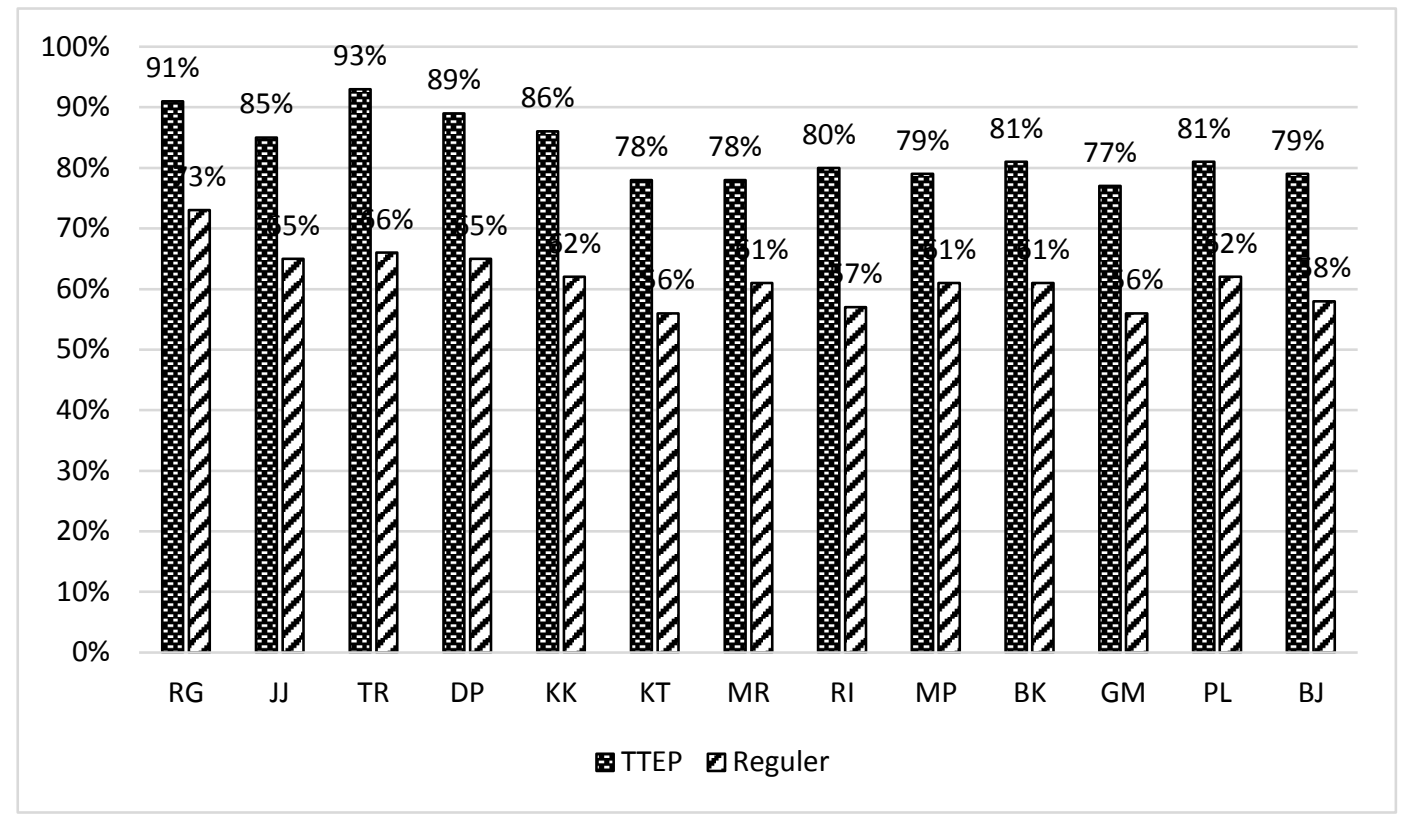

Gambar 3. Perbandingan karakter peserta didik kelas TTEP dan reguler

Gambar 3. menunjukkan perbandingan nilai karakter dari berbagai aspek. Jika dilihat dari rata-rata kedua kelas tersebyt memiliki perbedaan karakter sebesar $21 \%$. Pada karakter kelas TTEP terdapat persentase tertinggi mencapai 93\% sedangkan pada kelas regular persentase tertinggi mencapai $73 \%$. Pada kelas TTEP ada 25 peserta didik masuk dalam kategori karakter sangat baik, sedangkan kelas reguler hanya 3 peserta didik. Pada kategori karakter baik di kelas TTEP berjumlah 4 peserta didik, sedangkan di kelas regular adaa 14 peserta didik. Di kelas reguler ada 16 peserta didik masuk dalam kategori sedang dan kelas TTEP tidak ada yang masuk dalam kategori sedang.

\section{PEMBAHASAN}

Nilai karakter dari kelas reguler dapat dikatakan cukup baik. Jika dibandingkan dengan kelas TTEP, maka perlu adanya pengembangan karakter pada kelas reguler karena ada beberapa aspek dari karakter kelas reguler yang masuk dalam kategori sedang (Sofli dan Sudrajat, 2014). Hal tersebut bertujuan untuk mencipkan generasi yang berkualitas. Pendidikan tidak hanya membentuk insan Indonesia yang cerdas, namun juga berkepribadian atau berkarakter (Koesoema, 2007)). Sehingga dengan amanah tersebut diharapkan lahir generasi bangsa yang berprestasi danjuga berkarakter baik. Pendidikan tidak hanya bertujuan menghasilkan prestrasi akademik saja, namun juga dalam hal perkembangan psikologis ataupun karakter yang baik pada individu ataupun peserta didik (Budiningsih, 2011). 
Nilai-nilai untuk pendidikan budaya dan karakter harus dikembangkan disekolah (Hidayat dan Ramadhan, 2016). Tujuan pendidikan menengah kejuruan diantaranya yaitu mengembangkan potensi peserta didik agar menjadi warga negara yang berakhlak mulia, sehat, berilmu, cakap, kreatif, mandiri, demokratis dan bertanggung jawab. Hasil dari karakter peserta didik kelas reguler bisa dikatakan masuk dalam kategori baik. Jika dilihat dari masing-masing aspek dari karakter peserta didik, maka belum bisa masuk dalam kategori baik dan tidak sesuai dengan teori diatas. Hal tersebut karena masih ada beberapa aspek karakter yang mendapatkan skor persentase dengan kategori sedang, yaitu gemar membaca 56\%, rasa ingin tahu $57 \%$, bertanggung jawab 58\%, dan kreatif 56\%. Kondisi tersebut memerlukan adanya pengembangan karakter dalam kelas reguler.

\section{KESIMPULAN}

Kesipulan penelitian ini yaitu bahwa pembentukan karaakter yang baik sangat dibutuhkan oleh industri. Ada perbedaan karakter perserta didik pada kelas TTEP dan reguler yang dipengaruhi oleh berbagai faktor. Perbedaan karakter tersebut akan berpengaruh pada jenjang pendidikan selanjutanya atau di tempat kerja.

\section{REFERENSI}

Asmani, J. M. (2012). Internalisasi Pendidikan Karakter di Sekolah. Yogyakarta: Diva Press.

Koesoema A. D. (2007). Pendidikan Karakter Strategi Mendidik Anak di Zaman Global. Jakarta: PT Gramedia.

Budiningsih, C. (2011). Karakteristik Siswa sebagai Pijakan dalam Penelitian dan Metode Pembelajaran. Jurnal Universitas Negeri Yogyakarta, 30(1), 160-173.

Darmadi, H. (2017). Pengembangan Model Metode Pembelajaran dalam Dinamika Belajar Siswa. Yogyakarta: Budi Utama.

Djamarah, S. B. (2008). Psikologi Belajar. Jakartra: Rineka Cipta.

Hidayat, U. P. dan Ramadhan, R. M. (2016). Pendidikan Karakter di Sekolah. Sukabumi: Yayasan Budi Mulia Sukabumi.

Lestari, P. dan Sukanti. (2016). Membangun Karakter Siswa Melalui Kegiatan Intrakulikuler, Ekstrakulikuler dan Hidden Curriculum. Jurnal Penelitian, 10(1), 71-96. 
Sitanggang, N. dan Saragih, A. H. (2013). Studi Karakteristik Siswa SLTA di Kota Medan. Jurnal Teknologi Pendidikan, 6(2), 185-196.

Slamet, P. H. (2011). Pendidikan Karakter dalam Prespektif Teori dan Praktek. Yogyakarta.

Sofli, dan Sudrajat, A. (2014). Peningkatan Karakter Siswa Melalui Pembelajaran IPS Terpadu Model Nested di SMP Negeri 3 Banguntapan Bantul. Jurnal Harmoni Sosial. 1(1), 8395.

Sunarto, H. dan Hartono, B., Agung. (2008). Perkembangan Peserta Didik. Jakarta: Rineka Cipta. 